Dziawgo, D., Féria, I., \& Saúde, S. (2017). Higher Education Funding: comparative analysis of Portugal and Poland public systems. Copernican Journal of Finance \& Accounting, 6(1), 33-53. http:// dx.doi.org/10.12775/CJFA.2017.002

\author{
Danuta Dziawgo* \\ Nicolaus Copernicus University in Toruń \\ ISIDRO FÉRIA** \\ Polytechnic Institute of Beja \\ SANDRA SAÚDE ${ }^{* * *}$ \\ Polytechnic Institute of Beja
}

\title{
HIGHER EDUCATION FUNDING: COMPARATIVE ANALYSIS OF PORTUGAL AND POLAND PUBLIC SYSTEMS
}

Keywords: higher education institution, funding, public education, algorithm of financial funds division.

J E L Classification: G38, H75, I23, I28, H52.

Abstract: In Europe governments remain a primary funding source for higher education institutions. In this context, reflections on higher education funding models have been discussing since knowledge has been increasingly perceived as an essential condition for economic growth and the creation of wealth.

Date of submission: May 30, 2016; date of acceptance: June 20, 2017.

* Contact information: ddziawgo@umk.pl, Faculty of Economic Sciences and Management, Nicolaus Copernicus University in Toruń, Gagarina 13a, 87-100 Toruń, Poland, phone: +48566114901.

** Contact information: Isidro Lourenco Rodrigues Gois Féria, iferia@ipbeja.pt, Departament of Management Studies, Polytechnic Institute of Beja, Rua Pedro Soares S/N, 7800-296 Beja, Portugal.

*** Contact information: Sandra Isabel Gonçalves da Saúde, ssaude@ipbeja.pt, Department of Education and Social Sciences, Polytechnic Institute of Beja, Rua Pedro Soares S/N, 7800-296 Beja, Portugal. 
The aim of the elaboration is to draw attention to selected aspects of the problem of public higher education funding as exemplified by Portugal and Poland which can be viewed as an important market concerning the number of citizens and the European Union membership. In the article description, comparison and case study methods were used.

\section{IIITRODUCTION}

In Europe, the massification of higher education over the last three to four decades has resulted in substantial increase in the level of public funds allocated to higher education institutions. Financing higher education, tuitions, and costs that come with studying, have become a current issue. For the European states, funding is a major steering mechanism for their higher education systems. Funding mechanisms are closely linked to general policy choices concerning higher education (Jongbloed, 2004; Barr, 2003).

Similarly to all continents, in Europe governments remain a primary funding source for higher education institutions. In this context, and due to the present financial crisis, reflections on higher education funding models gained on their topicality, given the existing additional pressure for the rationalization of the available public funds. Particularly in recent years, higher education institutions have been confronted with the reality of smaller public funds available and, consequently, the need for limiting their budgets.

This has been a trend, particularly observed in Portugal and Poland in the last 5 years, where public investment either consistently remains relatively stable (Poland) or decreases (Portugal). Especially in Portugal the decrease of available public budget has been accompanied, firstly, by an appeal for a more responsible financial management due to imperatives of the global financial crisis and, secondly, by a continued decline of the number of students enrolling for higher education since the beginning of the millennium. After a period of strong expansion of supply and demand for higher education, registered in the 90 s, follows a consolidated period of contraction, strongly associated with population aging.

Portugal and Poland are members of the European Union with distinct socio-economic and historical identities, but simultaneously, with many parallelisms in terms of their higher education systems and funding models evolution. Higher Education in Poland and Portugal have a network of schools covering the area of the whole country (with a significant presence of the private sector) 
which grew and strengthened especially during the 90 s, just as the first state regulations were formulated on the model and rules of financing.

\section{THE RESEARCH METHODOLOGY AND THE COURSE OF THE RESEARCH PROCESS}

The working paper focuses on education, and hence on human capital development that is key for micro- and macroeconomic success. The article identifies and discusses synthetically area in financing higher education institutions. The basic method used in the process of writing was a critical analysis of literature and law regulations concerning the HEIs as well as own over the time observations based on different case studies analysis. In the article description, comparison and case study methods were used.

\section{HigHER EDUCATION AS AN INVESTMENT - SIGNIFICANCE IN ECONOMIC GROWTH AND EMPLOYMENT}

Across Europe there is currently a wide discussion on the role of the state in education and, more precisely, on the value of the mission and the significance of higher education in society and economic dynamics. Since 20th century we have been living in a time of dramatic changes, which give rise to scenarios of social instability and a strong atmosphere of uncertainty. These changes occur at various levels, not only economic but also political, sociocultural and technological. The current models of production and work organization, based on flexibility and competitiveness, require workforce with constantly updated skills and knowledge; in other words, workers with access to continuous learning, in order to update, expand and reshape their qualifications. In this context, knowledge has been increasingly perceived as an essential condition for economic growth and the creation of wealth. The performance of individuals, enterprises, regions and countries is structurally determined by their capacity to learn and adapt to new circumstances (Arbo \& Benneworth, 2007).

In the last four decades, education and training have gained an outstanding importance and must be considered as crucial pillars of world economy. Competitiveness and productive as well as technological innovations (essential elements of today's paradigm of global economy) result from knowledge capital. From this point of view, learning countries and regions are those which tend to invest in education and lifelong learning as strategic pathways to the qualification of their resources, as well as to business revitalization, job mar- 
ket requalification, and economic survival. The potential for the development and economic growth of a country or territory is strategically linked to the value of their social and knowledge capital (Arbo \& Benneworth, 2007). In this scenario, higher education is recognized as having a critical role in promoting interdisciplinary expertise, with a high level of specialization and supported by applied research. It provides the community with qualified human resources, scientific investigation, services, and technological transfer (Gibbons et al., 1994).

Higher education is currently and globally, mainly in today's context of financial crisis, a fundamental asset to the development of any territories, essentially to those with demographic and economic low density.

Several studies establish a direct relationship between human capital qualification and regional development. Many others prove that, besides good facilities, efficient transport network, a rich cultural and natural heritage, an effective productive dynamics or a young and active demographic stock, the investment in and the existence of educational resources, mainly higher education, are fundamental (Simões Lopes, 1987; Castells, 1994). Human resources with higher education qualifications are critical to leverage the technological and entrepreneurial potential of human capital in a region. According to Garrido-Yserte and Gallo-Rivera (2010, p. 39) “(...) higher education [organizations] are not only recognized as institutions that offer education and applied research but also as key players in the regional/local development."

On the one hand, the provision of higher education has a direct impact on the demographic subsystem by attracting new residents (students and teaching and non-teaching staff), as well as by retaining those who remain, due to available training and/or job opportunities. On the other hand, this demographic dynamics has a direct impact on the pattern of consumption and consumer typology, on the demand for cultural goods and leisure, and on the labor market characteristics. In conclusion, it has a multitude of interacting impacts.

If we focus the analysis on economic effects, we come to the conclusion that they can also be subdivided into groups. Table 1 presents, according to Lambooy (1996), the impacts of Higher Education Institution (HEI) for the economic activity. 
Table 1. Economic impacts of HEIs with examples

\begin{tabular}{|l|l|}
\hline \hline \multicolumn{1}{|c|}{ Economic effect of HEIs } & \multicolumn{1}{c|}{ Example } \\
\hline \hline Employment at the HEI & Number of jobs at HEl and related institutions \\
\hline Income of HEI & $\begin{array}{l}\text { State contributions, tuition fees, financial benefits e.g. from book sales \& mer- } \\
\text { chandising }\end{array}$ \\
\hline HEI spending & Purchase of goods and services by HEI \\
\hline $\begin{array}{l}\text { Income and spending } \\
\text { of HEl employees }\end{array}$ & $\begin{array}{l}\text { Wages, salaries, and social security costs. Expenditures in shops, on entertain- } \\
\text { ment and culture, and on public transportation }\end{array}$ \\
\hline Labour market effects & Providing educated labour. Increased productivity effect. \\
\hline Spin-off of business & $\begin{array}{l}\text { Companies founded by (former) students and HEl employees, whether or not } \\
\text { implementing academic knowledge and technology }\end{array}$ \\
\hline Marketing of knowledge & The sales of knowledge in a variety of forms: from ideas and courses to patents. \\
\hline \hline
\end{tabular}

S o u r c e : adapted from Lambooy, 1996, as cited in Pellenbarg, 2005.

This can be viewed as an impact at macro level. Following an "input-output" approach, in other words, the combined analysis of the impacts generated by demand and supply/product, Kelly and McNicoll (2011) synthesize the socioeconomic effects of HEI in the model presented in figure 1.

The studies aiming to assess the role of HEIs in socioeconomic development increasingly stress the deep-seated interdependence between economic and social impacts. The effect on economic activity has inherent impacts on the social dynamics of the territory. There are, indeed, multiple transversal effects which, when considered globally (direct and indirect impacts, short, medium and long term, demand-side or supply-side), allow us to determine the structural role an HEI plays in strengthening not only local economy but also, and above all, in transforming and developing the whole regional dynamics. This impact is particularly relevant and expressive in territories where economic isolation is more evident and/or where the provision of higher education is minimal.

Higher education has a structural role in the economic, cultural, political and social dynamics of the territory where it is located. It is, therefore, the responsibility of HEIs to adjust their mission to the context, in the fields of education, applied research, knowledge transfer, and economic as well as entrepreneurial development. 
Figure 1. Socioeconomic impacts based on demand and supply

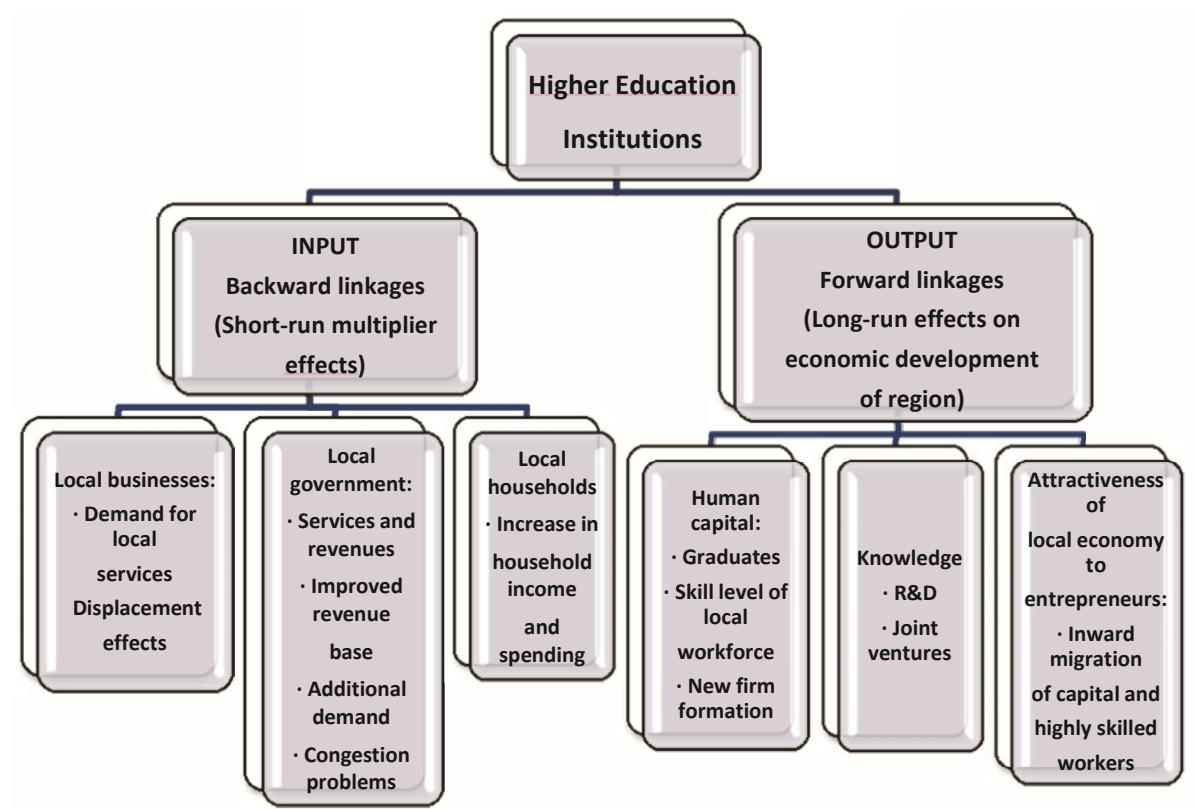

S o u r c e : Kelly \& McNicoll, 2011, p. 29.

On the importance of education in the dynamics of a region or a country, it is believed that:

"Human resources will always be the most valuable and promising component of the endogenous potential, and this will increase with qualifications. Hence the strategic, structuring role education and training in general play in the development process" (Simões Lopes, 1996, p. 4).

At the same time, we cannot ignore the effect of higher education at the micro level of an individual citizen, either. Extending horizons results in a number of elements which, in consequence, increases the level of better personal life management. It is noticeable in the feeling of financial security, responsible credit decisions, setting up a family and/or the number of children in the family.

An analysis should be completed with sociological aspects concerning university graduates such as:

- Helping to gain life stability,

- Increasing personal self-esteem,

- Facilitating international contacts, 
- Familiarizing with the culture of other countries,

- Increasing the level of mobility,

- Developing knowledge and creativity,

- Higher level of emotional maturity leading to higher level of personal responsibility,

- Rising the level of expectations towards environment, such as quality of services and products, local and state governments,

- Higher awareness of consequences of choices concerning both rational purchasing of products and services as political choices.

Consequently, the massification of higher education witnessed in the last few years has become an essential foundation to society's economic development. This idea is shared by Arbo and Benneworth (2007) when they argue that, nowadays, the intellectual capital is considered a critical element to sustainable economic development, so education must be considered today the most valuable resource of any region.

\section{The Polish and the Portuguese Higher Education Networks}

\section{The Polish Higher Education Network}

The Polish Higher Education Network is different from some other countries due to a strategy maintained by the Polish Ministry for Science and Higher Education for a long period of time and due to a significant number of private HEIs.

The strategy realized by the Ministry was formed on a concept of non-formulate strategy. Therefore, the Ministry for many years has not had a formalized strategy. It justifies the independence of HEIs in the area of education and scientific research. The Ministry occasionally undertakes actions such as encouraging HEIs to create new fields of studies by financially supporting these studies. But due to a change at the position of the Minister, the strategy for both higher education and scientific research starts being prepared.

In Poland students in public HEIs do not pay for their education. Only parttime students ${ }^{1}$ and students of private HEIs pay for studies themselves. Also, central budget finances only a limited number of vacancies ${ }^{2}$. Due to the increas-

\footnotetext{
1 Saturday and Sunday studies.

2 Currently, public institutions can increase a number of non-paid students up to $2 \%$ yearly; for private institutions such a limit does not exist.
} 
ing number of young people ending their secondary level of education at the beginning of new century, it resulted in establishing such a high number of private higher education schools and part-time studies for increasing their financial resources. Thus, the cost of obtaining the diploma shifted from central budget into those who studied. Now, due to a decreasing number of young people, private schools facing financial difficulties are withdrawing from the educational market. This same is happening in part-time studies, so the situation is going back to the staring point.

But still we can say, that according to numbers, in Poland higher education system is highly atomized. The system comprises of 401 actively operating institutions. Public HEIs correspond to approximately $1 / 3$ of all active HEIs (with 19 universities and 18 polytechnics). Also, in 1998, meeting the demand of work market, vocational public HEIs were established. They educate students exclusively at BA level. They were created in smaller towns to extend access to higher education (currently 36 such institutions are operating).

The highest number of students was in 2005 - nearly 2 million. Since 2006 the number of students has been decreasing to currently 1.4 million students. The decrease resulted mainly from a declining population number at the age of 19-24. But still public institutions are the most popular regarding the number of students.

In Poland, higher education network covers the whole country. The public HEIs are placed in towns over 200,000 inhabitants. But, of course, the highest number of institutions is in the capital - Warsaw. It may be concluded, that the number of HEIs is strongly correlated with the number of inhabitants and also with the economic power of a specific region, which increases a possibility to find a well-paid job.

Also some crucial changes in regulatory environment should be mentioning. Since the beginning of 90 s, after starting the conversion from socialism to capitalism, higher education system in Poland has been undergoing significant reforms. In general, along with existing public schools, non-public schools have been set up. Due to Bologne system 5 year-long studies were divided into 2 levels: first-cycle program (BA) for 3 years, second-cycle (MA) for 2 years, but at the same time for several fields of studies unified master studies for 5 or 6 years have still been functioning (such as law, art conservation, medicine). Also, a third-level of studies lasting 4 years was created for Ph.D. students.

In 2005 a new higher education act was introduced resulting in changes in financing HEIs as well as it standardized parts of programs for each field of 
studies. It also imposes requirements for a minimum number of academic lectures as well as teachers for each field of studies. Moreover, a central institution for evaluating the quality of studies and meeting the criteria required by law was established.

The next significant legal changes took place in 2012 and 2014. Due to them the process of achieving scientific degrees was simplified and shortened. Also, private HEIs were included in the system of students financial support and for financing scientific research from the Ministry of Science and Higher Education funds. In consequence, we can assume, that the whole HEIs sector consists of $30 \%$ public and $70 \%$ non-public HEIs. Non-public HEIs educate $20 \%$ students while public HEIs $80 \%$. Universities (public) constitute $4 \%$ of all HEIs sector and educated $30 \%$ of all students.

Another important change was to replace a required minimum number of total course hours by ECTS points. Also, it should be mentioned, that public HEIs in Poland are privileged with independence originating from the Middle Ages. The rector is elected by the academic community. The Minister can suspend the rector or withdraw rector's competences only in a few cases. One of them are financial results and financial difficulties.

According to Higher Education Act, if the value of summed losses in the last 5 years excide $25 \%$ of public fund transfer to public HEI in the previous year, then that institution is obliged to prepare a recovery program to balance its financial results within 3 years. If the obtained results are not satisfactory for the minister or the institution did not prepare a recovery program, then the Minister appoints a temporary rector (for max. 3 years). At that moment the previous rector is suspended and the senate power is limited - all financial decisions are removed from its competences.

\section{The Portuguese Higher Education Networks}

The Portuguese higher education system is a binary system, integrating universities and polytechnic institutes, which differ in dimension and legal framework. The system comprehends a total of 132 institutions. Public higher education corresponds to about $1 / 4$ of all the institutions, 14 of which belong to the university sub-system (13 universities and 1 university institute). It also includes 15 polytechnic institutes and 5 non-integrated polytechnic schools. The remaining institutions are private or belong to the military and police higher education network. 
Some institutions in both sectors, public and private, provide university and polytechnic education at the same time. Such is the case of the Universities of: Minho, Alto Douro e Trás-os-Montes, Aveiro, Açores, Madeira, Évora and Algarve, as well as the Military Academy and the private institution: Egas Moniz - Cooperativa de Ensino Superior. The public sector has over $80 \%$ of the students.

The highest number was reached in 2002 and 2003 with a total of over 400 thousand students (nearly $70 \%$ in the public HEI). Since then, the number of students has been decreasing to over 350 thousand of students currently. The consistent decrease of students, enrolled in Higher Education, results mainly from the declining of the population number with age between 19 to 24 years and also due financial crisis that Portugal has passed mainly since 2009.

Currently, and following the implementation of the Bologna process, Portuguese HEIs provide 3 types of academic degrees: licenciate, master, and PhD. The provision of PhD courses is limited to universities, though.

In Portugal, the higher education network covers the whole country and public HEIs are more territorially dispersed than private ones, which tend to concentrate in the metropolitan areas of Lisbon and Oporto, as well as in more densely populated regions. Polytechnic institutes are located in areas with lower socioeconomic and population density and farther from big urban areas, except for the Polytechnic Institutes of Oporto, Lisbon, Coimbra and Setubal.

Since the Revolution of April 1974, higher education has expanded significantly in Portugal. This phenomenon was a result of a growing number of institutions and the increasing number of students, unique in the whole of Europe, especially during the first decade of the 21st century (Amaral \& Fonseca, 2012).

\section{The Polish Higher Education Funding System}

In Poland, total public budget for science and higher education can be seen as relatively stable (1.28 - 1.32\% of GDP). Partially it is thanks to European Union money. During the last 5 years in Poland, the lowest budget has been dedicated to science and higher education in 2012 and 2013. The expenditures for science are at $0.4 \%$ GDP and for higher education at $0.9 \%$ GDP. 


\section{The Legal Frame}

Currently, HEIs are mainly influenced by the following laws: Higher Education Act, Rules of Financing Science Act, Scientific Degrees and Titles Act. All of them include some parts dedicated to financing in the area of education, scientific research and academic promotion. Usually those acts change once in two years.

\section{Characteristics, tools and procedures}

In Poland there are 2 main domains for financing HEIs: funds dedicated to financing research (science) and funds to maintain HEIs activity (for staff, students, maintenance, etc.). It should also be mentioned, that other money flows directly to students (eg. material assistance or scholarships for $30 \%$ best in each field of studies according to grades).

Funds dedicated to science come from several streams:

a) From the Ministry of Science and Higher Education:

- Maintenance of research capacity,

- Development of young scientist (up to 35 years old),

- Maintenance of special research equipment,

- Maintenance of virtual library of science,

- Some others such as restructuring or unexpected events resulting in damages.

b) From funds redistributed by special institutions or programs (naming the main of them):

- National Science Centre,

- National Centre for Research and Development,

- National Program for Humanities Development.

c) From other ministries (such Ministry of Health, Ministry of National Defense, Ministry of the Interior, Ministry of Sport and Tourism, Ministry of Culture and National Heritage),

d) From European Union structural funds managed by voivodship marshals.

Funds dedicated to HEIs for maintaining education flow from responsible ministries. The main resource is named 'basic subsidy' and is explained in detailed below. It should be pointed out, that each criterion is relativized to the whole HEIs population. That fund can be used for all HEIs expenditures connected with full-time students and Ph.D. students, salaries of academic teach- 
ers and non-academic teachers, infrastructure maintenance (buildings, equipment, materials). Usually that fund sustains about $70-80 \%$ of public money received by public HEIs (table 2).

Table 2. Criteria used in the funding formula used 2015-2016 for public HEIs

\begin{tabular}{|c|c|}
\hline $\begin{array}{l}\text { Terms in the funding } \\
\text { formula }\end{array}$ & Description \\
\hline $\begin{array}{l}\text { Permanent transfer } \\
\text { [weight 65\%] }\end{array}$ & Amount of money from previous year due to finance stabilization \\
\hline $\begin{array}{l}\text { Number of students } \\
\text { and Ph.D. students } \\
\text { [weight } 35 \% \text { ] }\end{array}$ & $\begin{array}{l}\text { Number of students for all the full-time fields of studies (factor } 1 \text { ) } \\
\text { Number of full-time Ph.D. students divided into } 2 \text { groups: those who receive scholar- } \\
\text { ship* from HEI (multiplied by factor } 5 \text { ) and those without scholarship (factor } 1 \text { ) } \\
\text { Funding depends on cost of specific field of studies; ministry published a factor (as form } \\
\text { of conversion index) from } 1 \text { to } 3 \text { (eg. } 3 \text { for medicine, pharmacy, veterinary; } 2.5 \text { for phy- } \\
\text { sics, chemistry, biology, technical studies, arts; } 1.5 \text { for economics; } 1.0 \text { for law, theology) } \\
\text { Number of foreigners who learn for } 1 \text { year Polish language and than will study in Poland } \\
\text { in Polish (multiple by factor } 1.5 \text { ) }\end{array}$ \\
\hline $\begin{array}{l}\text { Academics } \\
\text { [weight 35\%] }\end{array}$ & $\begin{array}{l}\text { Number of academics with full professors title** (factor } 2.5 \text { ) } \\
\text { Number of academics with habilitation degree (factor } 2 \text { ) } \\
\text { Number of academics with doctor (Ph.D.) degree (factor 1.5) } \\
\text { Number of academics with MA degree (factor } 1 \text { ) } \\
\text { Number of foreign academics teaching } 60 \text { hours in previous academic year, staying in } \\
\text { HEl longer than } 3 \text { months (factor } 5 \text { ) } \\
\text { Number of foreign academics teaching } 60 \text { hours, staying in HEl shorter than } 3 \text { months } \\
\text { (factor } 4 \text { ) }\end{array}$ \\
\hline $\begin{array}{l}\text { Proportional deve- } \\
\text { lopment of education } \\
\text { [weight } 10 \%]\end{array}$ & $\begin{array}{l}\text { Square root of number of academic teachers multiplied by square root of number } \\
\text { of students and Ph.D. students multiplied by different factors as: } \\
2.0 \text { - number of full-time MA students and unified master studies } \\
1.0 \text { - number of full-time BA students } \\
2.5 \text { - number of full-time Ph.D. students }\end{array}$ \\
\hline $\begin{array}{l}\text { Research } \\
\text { [weight 10\%] }\end{array}$ & $\begin{array}{l}\text { Number of grants financed by public budget by special government institution such as: } \\
\text { National Science Centre, National Centre for Research and Development, National Pro- } \\
\text { gram for Humanities Development, Development of Academic Sports (factor } 1 \text { if HEls is } \\
\text { leader and } 0.5 \text { if consortium member) } \\
\text { Number of grants financed by international programs (factor } 2 \text { for leader and } 1 \text { consor- } \\
\text { tium member) } \\
\text { Number of grants financed under 'Horizon 2020' Program (factor } 4 \text { for leader and } 2 \text { for } \\
\text { consortium member) }\end{array}$ \\
\hline $\begin{array}{l}\text { Academic authorization } \\
\text { [weight } 0.05 \% \text { ] }\end{array}$ & $\begin{array}{l}\text { Number of rights to give habilitation degree in scientific research area (factor 2) } \\
\text { Number of rights to give doctoral (Ph.D.) degree (factor 1) }\end{array}$ \\
\hline $\begin{array}{l}\text { International exchange } \\
\text { [weight } 0.05 \%]\end{array}$ & $\begin{array}{l}\text { Number of Polish students and Ph.D. students who went to study abroad for } 3 \text { months } \\
\text { or longer under international exchange program (factor } 1 \text { ) } \\
\text { Number of foreign students and Ph.D. students who came to study for } 3 \text { months or } \\
\text { longer under international exchange program (factor } 3 \text { ) }\end{array}$ \\
\hline
\end{tabular}

Notes: * Scholarship for Ph.D. students has to be paid for 12 months. The minimum is $60 \%$ of minimum salary for teachers at the assistant position.

** Full professor is a title given by the President of Poland.

S o u r c e : own study based on appropriate law regulation. 
As it was shown in table 2, the main source of money in the algorithm comes from academic staff - number and their scientific degree as for full professor factor is 2.5 for M.A. staff. Also, for management reason, the public HEIs received not less than $65 \%$ subsidy from previous year. In 2015 value differences compared to 2014 were lower than $2 \%$.

In result of law regulation changes, private HEIs also gain some money from public system. Approximately $98 \%$ financial resources still flow to public institutions but in value, private HEIs eg. for science from budget of Ministry of Science and Higher Education in 2014 received over 4.5 million EUR.

\section{The Portuguese Higher Education Funding System}

\section{The Legal Frame}

The current legal framework for higher education funding is based on Law from 2003, with changes introduced in 2005.

In its goals, the law intends to ensure compliance with the national priorities of educational policy, by supporting higher education institutions in the performance of duties of a quality education as well as helping the promotion of development plans.

The objectives of the law, also include the incentive to seek funding sources of a competitive nature on the basis of quality and excellence, the promotion of the right to equal opportunities for access, attendance and school success, appreciation of merit, dedication and academic success of students, regardless of their economic capabilities.

\section{Characteristics, tools and procedures}

The formula mentioned above shall contain the criteria, default values, and performance indicators, such as: the relative standard for teaching staff/student; the relative standard for teaching staff/non-teaching staff; incentives for qualification of teaching and non-teaching staff; indicators of quality teaching staff of each institution; the efficiency of educational courses; the efficiency of scientific master's and doctorate; the efficiency of institutions management; the classification of merit resulting from the evaluation of the course/institution; budget structure, reflected in the ratio of personnel expenses and other operating expenses and the merit classification of research units. 
The funding system does not calculate absolute budget values, but merely allocates the available plafond to the institutions thus avoiding the idea of cuts to the calculated values. It should be noted that under the current context of excess capacity, higher education institutions compete for students and generally is necessary to allocate extra funding outside the formula and the procedure subvert the transparency of the system (Rosa, Tavares \& Amaral, 2006).

This formula (table 3) was based on the overall number of students, but included the following quality factors:

- Qualification of teaching staff, as measured by the fraction of PhDs in the total number of teachers of each institution.

- Graduation rate, as measured by two indicators:

a) The number of first cycle graduates;

b) The number of master and $\mathrm{PhD}$ degrees awarded

In addition, the formula included two institutional factors to answer to specific characteristics of each individual institution and training area:

- Average personal costs for each institution, to account for the specific characteristics of the teaching and non-teaching staff of each institution

- Specific student/teacher ratio for each scientific area.

Table 3. Criteria used in the Funding Formula developed for 2006, based on current funding law

\begin{tabular}{|c|c|}
\hline $\begin{array}{l}\text { Terms used } \\
\text { in the distributive funding formula }\end{array}$ & Descrition \\
\hline$A=$ & $\begin{array}{l}\text { Standard Ratio Teacher / Student (for each area it is the same for all insti- } \\
\text { tutions / schools). }\end{array}$ \\
\hline $\mathbf{B}=$ & $\begin{array}{l}\text { Standard Ratio non-teaching staff / Student (for each area it is the same } \\
\text { for all institutions / schools). }\end{array}$ \\
\hline$C=$ & Non-teaching Standard Ratio of the Central Administration / Student. \\
\hline $\mathbf{R D}=$ & Average cost of teaching staff. \\
\hline RND = & Average cost of non-teaching staff. \\
\hline \multirow[t]{2}{*}{$\mathrm{Cij}=$} & Cost Standard staff / Student in the institution i to the scientific area J. \\
\hline & $C i j=(1 / A \times R D+1 / A \times B \times R N D+1 / C \times R N D)$ where $C=1 / 116.3$ \\
\hline
\end{tabular}


Table 3. Criteria used in the Funding Formula developed for $2006 \ldots$

\begin{tabular}{|c|c|}
\hline $\begin{array}{l}\text { Terms used } \\
\text { in the distributive funding formula }\end{array}$ & Descrition \\
\hline \multicolumn{2}{|r|}{ Methodology and Procedures } \\
\hline \multirow[t]{3}{*}{$\begin{array}{l}\text { Overall Number of Students (Average } \\
\text { weight } 90 \% \text { ) }\end{array}$} & $\begin{array}{l}1 .^{\circ} \text { Calculation of } \mathrm{Cij} \text { (standard cost of staff / student to the various areas } \\
\text { of training). }\end{array}$ \\
\hline & $\begin{array}{l}\text { 2. }{ }^{\circ} \text { Calculating the cost factor by dividing the value of cost / student from } \\
\text { each training area by the national minimum. }(*)\end{array}$ \\
\hline & 3. ${ }^{\circ}$ Forecast students by field of study. \\
\hline \multirow[t]{4}{*}{$\begin{array}{l}\text { Quality Indicators } \\
\text { (Average weight 10\%) }\end{array}$} & 4. ${ }^{\circ}$ Calculation of pedagogical efficiency factor. \\
\hline & 5. ${ }^{\circ}$ Calculation of scientific efficiency factor. \\
\hline & 6. ${ }^{\circ}$ Calculation of graduation efficiency factor. \\
\hline & 7. ${ }^{\circ}$ Calculating the qualifying standard. \\
\hline \multirow[t]{6}{*}{ Results and Corrections } & $\begin{array}{l}8 .^{\circ} \text { Calculating the number of students by heavy training area }=\text { cost fac- } \\
\text { tor } x \text { forecast of number of students per area } x \text { coef. of graduation } x \text { Ind. } \\
\text { of qualification. }\end{array}$ \\
\hline & $\begin{array}{l}9 .^{\circ} \text { Calculation of number of heavy students from all areas of training } \\
\text { and all institutions. }\end{array}$ \\
\hline & $\begin{array}{l}\text { 10. Dividing the total of the ministry's budget by the total heavy stu- } \\
\text { dents of all institutions. }\end{array}$ \\
\hline & $\begin{array}{l}11 .^{\circ} \text { The result of the previous calculus corresponds to the amount } \\
\text { to be transferred by heavy student. }\end{array}$ \\
\hline & $\begin{array}{l}\text { 12. } .^{\circ} \text { Multiplies the amount to be transferred by heavy student by the } \\
\text { total number of heavy students from each institution, obtain the budget } \\
\text { to be to each institution. }\end{array}$ \\
\hline & $\begin{array}{l}13 .^{\circ} \text { After the formula results, it is necessary to apply the correction fac- } \\
\text { tors for some institutions during a given period of convergence. }\end{array}$ \\
\hline
\end{tabular}

Notes: * Cost factor to allow considering specific institutional characteristics, as well as to differentiate areas of study.

S o u r c e : own study based on appropriate law regulation.

To achieve specific objectives contract programs can be concluded with the institution of higher education in a time frame less than five years, aimed at supporting programs promoting school success, training of teachers and other staff; shares under the information society; support for the operation of interinstitutional courses, support for launching new courses in priority areas for the launch of the country; settlement of asymmetries between units; support 
the provision of specialized services to the community, support research projects of excellence and support the creation of new schools.

The funding formula is intended to provide a stable basis for institutional planning, while providing incentives to institutions to improve performance. The formula is also adjusted to stabilize funding changes from year-to-year, through a "cohesion factor" designed to protect low-performing institutions from excessive budget cuts. Capital funding is determined on a project-by-project basis and is linked to regional development plans. Investment plans are negotiated directly by the institutions with the Directorate General of the Ministry of Education.

Every student enrolled in a public higher education institution has to pay an annual fee fixed by each institution between the minimum and maximum amount. The current law allows public HEIs to set the value of undergraduate tuition fees between the minimum of 1.3 times the minimum monthly wage and the maximum determined by updating the value of 1941 by inflation.

During the expansion cycle, the funding formula was "appropriate" to promote growth of the system. The problem is that funding systems based on the number of students stimulate the higher education institutions to develop new courses, even if they are not related to their culture, mission and local and regional needs and it can lead to unsustainability of current higher education network, as is taking place in Portugal.

In Portugal imbalances have got worse especially because the expansion cycle have been "fed" by allocating funds through a distributive funding formula applied to the binary system (with totally different characteristics).

The identified problems inevitably lead to the reorganization of the current higher education network and a new financing model.

Currently, budgets will be maintain stable between 2016 till 2010, due a contract signed, in 2016, by all public universities and polytechnics with the government. It was assumed the compromise of not reducing the available budgets of the HEIs during this period. 


\section{Polish \& PORTUGUESE HIGHER EDUCATION FUNDING SYSTEMS - DIFFERENCES AND SIMILARITIES}

Table 4. Financing systems: Poland vs Portugal

\begin{tabular}{|c|c|c|}
\hline Financing Systems & Poland & Portugal \\
\hline Base of university's (core budget) & No & No \\
\hline $\begin{array}{l}\text { Performance contracts based on strategic } \\
\text { objectives }\end{array}$ & No & No \\
\hline $\begin{array}{l}\text { Funding for specific research projects, } \\
\text { awarded in the framework of competitive } \\
\text { procedures }\end{array}$ & Yes & Yes \\
\hline $\begin{array}{l}\text { Budget negotiation with funding body } \\
\text { based on a budget estimate submitted } \\
\text { by the institution }\end{array}$ & No & No \\
\hline $\begin{array}{l}\text { Budget negotiation by the funding body } \\
\text { based on past costs }\end{array}$ & No & No \\
\hline Unitary Model & Yes & Yes \\
\hline $\begin{array}{l}\text { Implementation of formula funding unit } \\
\text { cost model for teaching }\end{array}$ & $\begin{array}{l}\text { Funding formula } \\
\text { on the national level }\end{array}$ & $\begin{array}{l}\text { Funding formula } \\
\text { on the national level }\end{array}$ \\
\hline $\begin{array}{l}\text { Distinction between teaching and re- } \\
\text { search }\end{array}$ & Component for research $=10 \%$ & No distinction \\
\hline Criteria used in the teaching formula & Number of students and degrees & Number of students and degrees \\
\hline $\begin{array}{l}\text { Distinction between full-time } \\
\text { and part-time students }\end{array}$ & $\begin{array}{l}\text { Only full-time students are } \\
\text { weighted }\end{array}$ & No differentiation \\
\hline Planning of student numbers & $\begin{array}{l}\text { Estimation based on the develop- } \\
\text { ments in the past years } \\
\text { ( }+2 \% \text { previous year) }\end{array}$ & $\begin{array}{l}\text { Estimation based on the develop- } \\
\text { ments in the past years }\end{array}$ \\
\hline Price model versus distribution model & Distribution model & Distribution model \\
\hline Unit costs per student place in 2011 (euro) & Differ between fields of study & Differ between fields of study \\
\hline $\begin{array}{l}\text { Criteria of allocation considering field } \\
\text { of study and level } \\
\text { Weightings (or coefficients) are used as an } \\
\text { indirect form of government control over } \\
\text { education areas. }\end{array}$ & $\begin{array}{l}\text { Differentiation between four } \\
\text { groups } \\
\text { of disciplines: } \\
\text { A: } 3 \text { medicine, pharmacy, } \\
\text { veterinary } \\
\text { B: } 2.5 \text { physics, chemistry, biology, } \\
\text { technical, agriculture, forestry, } \\
\text { arts, firm, music, theatre, } \\
\text { fine arts } \\
\text { C: } 2.0 \text { mathematics, earth sci- } \\
\text { ences, health, physical culture }\end{array}$ & $\begin{array}{l}\text { Differentiation between seven } \\
\text { groups } \\
\text { of disciplines: } \\
\text { University System: } \\
\text { A: } 4.00 \text { Medicine and dentistry } \\
\text { B: } 3.56 \text { Performing arts } \\
\text { C: } 2.70 \text { Veterinary medicine } \\
\text { D: } 2.50 \text { Business sciences, engi- } \\
\text { neering sciences, pharmaceutical } \\
\text { sciences and agricultural sciences }\end{array}$ \\
\hline
\end{tabular}


Table 4. Financing systems...

\begin{tabular}{|c|c|c|}
\hline Financing Systems & Poland & Portugal \\
\hline & $\begin{array}{l}\text { D: } 1.5 \text { economics humanistic } \\
\text { science } \\
\text { E: } 1.0 \text { law, theology, } \\
\text { social science }\end{array}$ & $\begin{array}{l}\text { E: } 1.90 \text { Fine arts, architecture, } \\
\text { physical education and sport } \\
\text { and media } \\
\text { F: } 1.60 \text { Mathematics, statistics } \\
\text { and computing } \\
\text { G: } 1.20 \text { Economics, management, } \\
\text { tourism geography and languages } \\
\text { Polytechnic System: } \\
\text { A: } 3.50 \text { Performing arts } \\
\text { and sign language } \\
\text { B: } 2.40 \text { Nursing } \\
\text { and technical dentists } \\
\text { C: } 2.00 \text { Health technologies } \\
\text { D: } 2.00 \text { Technologies. } \\
\text { E: } 1.70 \text { Agricultural } \\
\text { and veterinary } \\
\text { F: } 1.50 \text { Basic education, media, } \\
\text { arts and sports } \\
\text { G: } 1.30 \text { Informatics } \\
\text { H: } 1.00 \text { Accounting, manage- } \\
\text { ment, tourism and service }\end{array}$ \\
\hline The setting fees & University sets fees & $\begin{array}{l}\text { University decides but ceiling set } \\
\text { by public authorities }\end{array}$ \\
\hline Ability to borrow money & $\begin{array}{l}\text { Universities are able to borrow } \\
\text { money }\end{array}$ & $\begin{array}{l}\text { Universities are not able } \\
\text { to borrow money }\end{array}$ \\
\hline Sale of university-owned real estate & $\begin{array}{l}\text { Sale of real estate requires per- } \\
\text { mission of public authorities }\end{array}$ & $\begin{array}{l}\text { Sale of real estate requires per- } \\
\text { mission of public authorities }\end{array}$ \\
\hline
\end{tabular}

S o u r c e : own study.

Table 4 shows that the financing systems (Polish and Portuguese) are very similar. The main differences occur at the level of tuition fees and the process of defining the weighting factors, which in Portugal assume different weights for each of the higher education systems.

In both countries, the process of allocation of funds resulting from the use of a single funding formula applied at the national level.

Behind funding formula was the need of the government to limit the rising costs of higher education in the last years.

Over time, researchers in higher education funding area have identified some of the main desirable characteristics of funding formulas. Some of these 
characteristics are summarized in table 5. The application of the matrix to Poland and Portuguese financing systems allows us to identify key areas for improvement in the financing systems.

Table 5. Analysis of recommended characteristics of funding formula

\begin{tabular}{|c|c|c|c|c|c|}
\hline \multirow{2}{*}{ Characteristics } & \multirow{2}{*}{ Summary Description } & \multicolumn{2}{|c|}{ Poland } & \multicolumn{2}{|c|}{ Portugal } \\
\hline & & Yes & No & Yes & No \\
\hline Equitable & $\begin{array}{l}\text { The funding formula should provide both horizontal equ- } \\
\text { ity (equal treatment of equals) and vertical equity (une- } \\
\text { qual treatment of unequals) based on size, mission and } \\
\text { growth characteristics of the institutions. }\end{array}$ & & $\mathrm{x}$ & & $x$ \\
\hline Adequacy-Driven & $\begin{array}{l}\text { The funding formula should determine the funding level } \\
\text { needed by each institution to fulfill its approved mission. }\end{array}$ & & $x$ & & $x$ \\
\hline Goal-Based & $\begin{array}{l}\text { The funding formula should incorporate and reinforce } \\
\text { broad goals of the state for its system of colleges and } \\
\text { universities as expressed through approved missions, } \\
\text { quality expectations and performance standards. }\end{array}$ & & $x$ & & $x$ \\
\hline Mission-Sensitive & $\begin{array}{l}\text { The funding formula should be based on the recognition } \\
\text { that different institutional missions (including differen- } \\
\text { ces in degree levels, program offerings, student readi- } \\
\text { ness for college success and geographic location) require } \\
\text { different rates of funding. }\end{array}$ & & $x$ & & $\mathrm{x}$ \\
\hline Size-Sensitive & $\begin{array}{l}\text { The funding formula should reflect the impact that rela- } \\
\text { tive levels of student enrollment has on funding require- } \\
\text { ments, including economies of scale. }\end{array}$ & $x$ & & & $x$ \\
\hline Responsive & $\begin{array}{l}\text { The funding formula should reflect changes in institutio- } \\
\text { nal workloads and missions as well as changing external } \\
\text { conditions in measuring the need for resources. }\end{array}$ & & $x$ & & $x$ \\
\hline $\begin{array}{l}\text { Adaptable to Econo- } \\
\text { mic Conditions }\end{array}$ & $\begin{array}{l}\text { The funding formula should have the capacity to apply } \\
\text { in a variety of economic situations, such as when the } \\
\text { state demand for higher education is increasing, stable } \\
\text { or decreasing. }\end{array}$ & $x$ & & $x$ & \\
\hline $\begin{array}{l}\text { Concerned with } \\
\text { Stability }\end{array}$ & $\begin{array}{l}\text { The funding formula should not permit shifts in funding } \\
\text { levels to occur more quickly than institutional managers } \\
\text { can reasonably be expected to respond. }\end{array}$ & $x$ & & & $x$ \\
\hline Simple to Understand & $\begin{array}{l}\text { The funding formula should effectively communica- } \\
\text { te to key participants in the state budget process how } \\
\text { changes in institutional characteristics and performance } \\
\text { and modifications in budget policies will affect funding } \\
\text { levels. }\end{array}$ & & $x$ & & $x$ \\
\hline $\begin{array}{l}\text { Adaptable to Special } \\
\text { Situations }\end{array}$ & $\begin{array}{l}\text { The funding formula should include provisions for sup- } \\
\text { plemental state funding for unique activities that repre- } \\
\text { sent significant financial commitments and that are not } \\
\text { common across the institutions. }\end{array}$ & $\mathrm{x}$ & & $\mathrm{x}$ & \\
\hline
\end{tabular}


Table 5. Analysis of recommended characteristics of funding formula...

\begin{tabular}{|c|c|c|c|c|c|}
\hline \multirow{2}{*}{ Characteristics } & \multirow{2}{*}{ Summary Description } & \multicolumn{2}{|c|}{ Poland } & \multicolumn{2}{|c|}{ Portugal } \\
\hline & & Yes & No & Yes & No \\
\hline $\begin{array}{l}\text { Reliant on Valid \& } \\
\text { Reliable Data }\end{array}$ & $\begin{array}{l}\text { The funding formula should rely on data that are ap- } \\
\text { propriate for measuring differences in funding require- } \\
\text { ments and that can be verified by third parties when } \\
\text { necessary. }\end{array}$ & $x$ & & $\mathrm{x}$ & \\
\hline Flexible & $\begin{array}{l}\text { The funding formula should be used to estimate funding } \\
\text { requirements in broad categories; it is not intended for } \\
\text { use in creating budget control categories. }\end{array}$ & & $x$ & & $x$ \\
\hline Incentive- Based & $\begin{array}{l}\text { The funding formula should provide incentives for in- } \\
\text { stitutional effectiveness and efficiency and should not } \\
\text { provide any inappropriate incentives for institutional } \\
\text { behavior. }\end{array}$ & & $\mathrm{x}$ & $\mathrm{x}$ & \\
\hline Balanced & $\begin{array}{l}\text { The funding formula should achieve a reasonable balan- } \\
\text { ce between the sometimes competing requirements of } \\
\text { each of the criteria listed above. }\end{array}$ & $x$ & & $x$ & \\
\hline
\end{tabular}

S o u r c e : adapted from: Desired Characteristics of a Funding Formula, http://www.hawaii.edu/ act188/docs/MGTAmer-funding_forumula_use.pdf.

The previous table allows us to verify and affirm that fund allocation models (Polish and Portuguese) can and should be improved and / or reformulated.

\section{ConClusions}

The comparative analysis of funding systems adopted in Portugal and Poland, that we analyze in this paper, helps to understand, by parallelism, the idiosyncrasies of the dominant Higher Education funding models in those two countries, particularly that combine two structural features, i.e.: 1) aging population versus decrease in the demand of higher education and 2) higher education system strongly dependent on the public care.

Since in Poland and in Portugal the existing funding systems favor the use of input indicators (namely, the number of students and the institution costs) rather than of output (associated with the performance and productivity metrics and impact), the reflection will lead us also to the discussion of the sustainability of this type of financing systems and of the assumptions of the public policies for higher education that underlined these procedures.

In the future papers we will analyze changes which are currently occurring and formulate some recommendations which should be taken into consid- 
eration during law formulation concerning financing such a sensitive sector as public higher education.

\section{REFERENCES}

Amaral, A., \& Fonseca, M. (2012). Portugal. Higher education and lifelong education in Portugal. In M. Slowey e H.G. Schuetze. Global Perspectives on Higher Education and Lifelong Learners (pp. 82-96). New York: Routledge. http://dx.doi. org/10.4324/9780203122495.

Arbo, P., \& Benneworth, P. (2007). Understanding the regional contribution of higher education institutions: a literature review. Education Working Paper, 9. OECD Publishing, http://www.oecd-ilibrary.org/docserver/download/51411n9dg538.pdf?ex pires $=1381157994 \& i d=i d \&$ accname $=$ guest $\&$ checksum $=$ C5948B875D083E9ACBBF D3B3D4ED3581 (accessed: 11.05.2017). http://dx.doi.org/10.1787/161208155312.

Barr, N. (2003), Financing higher education: Comparing the options, https://econ.lse. ac.uk/staff/nb/barr_HE_option030610.pdf (accessed: 13.05.2017).

Castells, Manuel et al. (1994). Estrategias para la reindustrialización de Asturias. Madrid: Civitas, Principado de Asturias.

Desired Characteristics of a Funding Formula, http://www.hawaii.edu/act188/docs/ MGTAmer-funding_forumula_use.pdf (accessed: 12.05.2017).

Garrido-Yserte, R., \& Gallo-Rivera, M. T. (2010). The impact of the university upon local economy: three methods to estimate demand-side effects, Ann Reg Sci, 44, pp. 39 -67. http://dx.doi.org/10.1007/s00168-008-0243-x.

Gibbons, M., Limoges, C., Nowotny, H., Schwarteman, S., Scott, P., Trow, M. (1994), The New Production of Knowledge: The Dynamics of Science and Research in Contemporary Societies, SAGE.

Jongbloed, B. (2004), Funding higher education: options, trade-offs and dilemmas, https://core.ac.uk/download/pdf/11460831.pdf (accessed: 17.05.2017).

Kelly, U., \& McNicoll, I. (2011). Through a glass, darkly: Measuring the social value of universities. National co-ordinating Centre for public engagement, retrieved from www.publicengagement.ac.uk (accessed: 11.04.2017).

Lambooy, J. (1996). Knowledge production, organisation and agglomeration economics. GeoJournal, 41(4), 293-300. http://dx.doi.org/10.1023/a:1006870309530.

Pellenbarg, P. H. (2005). How to calculate the impact of a university on the regional economy. A case study of the University of Groningen, Holland.

Rosa, M.J., Tavares, D.A., \& Amaral. A. (2006). Funding Systems and their Effects on Higher Education Systems. Country Study - Portugal.

Simões Lopes, A. (1987). Desenvolvimento regional - problemática, teoria, modelos. Lisboa: Fundação Calouste Gulbenkian. 
